\author{
(C) This is a post-peer-review, pre-copyedited version of the article published in \\ Revisiting the Scene of Writing: New Readings of Cixous, ed. Julia Dobson and Gill \\ Rye, special issue of Paragraph 23.3 (November 2000), pp.296-310.
}

\title{
AGONY OR ECSTASY? READING CIXOUS'S RECENT
}

\section{FICTION}

Since Cixous's work was first published over thirty years ago, her fiction has always met with extreme reactions. Readers either love it or hate it. It all depends, it seems, on whether her complex, poetical writing speaks to you, or not. At one end of the spectrum, aficionados celebrate her work with their own Cixousian readings of Cixous's texts; at the other, her writing is met with accusations of elitism, utopianism, her polysemic fiction just too difficult, too demanding of the reader, untranslatable, unteachable, even unreadable. ${ }^{1}$ This polarity in the responses to Cixous's work deserves further examination, especially given the implications of her polemical feminist-oriented essays of the 1970s which argue for the liberating and transformative power of literature: reading and the reader (thus Cixous's own readers) must be significant players in the processes of socio-political and psychological change that she envisages, although her small readership and the marginal status of her work means that the impact of her own writing will be limited. In the first instance, this article considers how and why Cixous's fiction continues to provoke such extreme reactions; it then goes on to engage more specifically with the idea that literature can bring about change by exploring the nature of 
the interaction between text and reader in Cixous's work through an analysis of Beethoven à jamais ou l'existence de Dieu. ${ }^{2}$

The terms, agony and ecstasy, of my title relate only in part to the extreme responses Cixous's work elicits; rather, their etymology provides the broader framework for my discussion of reading. 'Agony', meaning pain or anguish, also carries the sense of struggle from the Greek agon, a contest. Here, the relationship between Cixous's texts and the reader is considered in terms of agon, by highlighting some of the factors which operate on the reading of her work. The second term, 'ecstasy', signifies rapture. Its Greek root, ekstasis, literally means standing outside - beyond one's normal state of mind or self. In this respect, I consider what Cixous's fiction can give to the reader, arguing that s/he is encouraged to go beyond (as in ekstasis) - beyond the text, beyond the text/reader agon, beyond even the self (in the senses of thinking differently as well as ecstasy). ${ }^{3}$

Most post-Barthesian reading theory points to a two-way interaction between text and reader with both the text and the reader as sites of plurality. Reading is thus in a sense a 'cross-fertilisation' of what is in the text with what the individual reader brings to his or her reading; the reader acts as co-creator of the text, an active partner in meaning production. ${ }^{4}$ According to this framework, the reader is conceptualized as powerful but not completely free since the text itself to some extent always directs his or her interpretation, even if that direction is ultimately open-ended, as I argue in the case of Cixous's fiction. Among the various paradigms of interactive reading proposed by contemporary reading theorists, Lynne Pearce's model of the dialogue is most suitable to this particular dynamic of text/reader relations, conceptualizing reading not only in democratic and reciprocal terms, but also as taking place within a framework of power 
relations - or here, agon - between text and reader: a politics of reading. ${ }^{5}$ The reader invoked in this article is similar to Iser's concept of the 'implied reader', which, itself an effect of interpretation, enables the relationship between text and reader to be discussed in terms of the interaction between textual strategies and the act of interpretation, while, at the same time, allowing for differences between individual readers. ${ }^{6}$

Throughout Cixous's prolific and varied oeuvre, the presence of the/an author is unfailingly inscribed. The author-figure is a seductive figure, and indeed, for texts to have the transformative effect that Cixous champions, they first have to seduce their readers. ${ }^{7}$ Notably, it is not the seductiveness, or otherwise, of the real-life woman (Cixous) that is relevant here, but instead, the figure of the, or an, author which is made present within the body of the text. Nonetheless, the differentiation between the two is not always clear-cut. On the one hand, the blurred boundaries between fiction, theory and autobiography in Cixous's work, and the fact that the Cixousian narrator is nearly always also a writer writing, do inscribe a version of Cixous herself as an ever-present author-figure into her texts. On the other hand, the actual identity of this textual author-figure is always kept uncertain, unstable and ultimately unknowable. Thus, although Cixous's first-person narrator is not to be simply equated with Cixous herself, neither can she be fully separated from her.

As I have argued elsewhere in the context of gender and reading, the presence of an author-figure in Cixous's fiction in such textual practices as direct reader address is both controlling and generous, ${ }^{8}$ but its effects are not necessarily only applicable to gender-specific modes of reading. Although Cixous's early fictions were addressed to an indisputably female reader (addressed as a feminine 'you' or 'we'), a supposedly inclusive strategy but which in practice is of course alienating to many individual women 
readers, all Cixous's more recent fictions since the pivotal Le Livre de Promethea (The Book of Promethea), have constructed readers (lecteurs) as both male and female. ${ }^{9}$ One effect of direct address is to draw the reader into the text. In Jours de l'an (FirstDays of the Year), as indeed in much of Cixous's fiction, direct address includes the reader in the process of writing: 'Je vais vous faire un aveu: depuis dix jours j'essaie d'écrire une dernière page pour ce livre' (I'm going to make you an avowal: for ten days I've been trying to write a last page for this book). ${ }^{10}$ Here, the narrator/writing subject confides in the reader, sharing her difficulties with writing the text. Reader address is of course a positioning device, but in Cixous's work there is often a generous outcome. At the end of Jours de l'an, the book which is being written throughout the duration of the text is left unfinished to fly away with 'un grand bruit d'ailes' (276) (the loud sound of wings) (187), undoubtedly released to its readers to contribute their part in its creation. A similar relinquishing of the text by the 'author' to her readers takes place at the end of both Cixous's L'Ange au secret and Le Livre de Promethea.

The author-figure is also made present by the self-referential character of Cixous's work. Fiction and theoretical texts are interdependent, echoing each other in terms of themes, analyses and, even, identical passages: 'Il y a une façon de dire tulipe qui tue toute tulipe. Il y a une façon clarice de faire-tulipe, et de la tige jusqu'aux prunelles je vois comme la tulipe est vraie"11 (There is a way of saying 'tulip' that kills every tulip (tue toute tulipe). There is a Clarice way of making-the-tulip, and from the stem to the eye's pupils, I see how the tulip is real). Exactly the same words appear, in the original French, in both the essay 'L'Approche de Clarice Lispector' and the fiction text Illa. Indeed, since Cixous so readily and frequently identifies herself in both essays and fiction with the Brazilian writer Clarice Lispector, the multitude of references to 
Lispector in Cixous's work also contributes to its self-referentiality. Cixous's essays offer useful insights into her fiction (and vice versa), but this can be as limiting as it is illuminating if it means that they are read principally from one particular (authoritative) perspective: her own theoretical framework.

If the self-referential character of Cixous's work means that her reader is contained within the Cixous corpus, sent from one Cixous text to another and back again, the heavily intertextual nature of her writing is much more open-ended, leading the reader out from the Cixousian oeuvre to an array of literature and art from a wide range of cultures. This positive effect must, however, be offset against the anxiety intertextuality can induce in the reader. Indeed, many of the problems that readers seem to experience with Cixous's writing are partly due to the wealth of intertextual references which make it both so rich and so dense. ${ }^{12}$ Julia Kristeva, theorizing the phenomenon of intertextuality and like Cixous, the revolutionary potential of literature, speaks of all texts as being under the 'jurisdiction' of other texts. ${ }^{13}$ Kristeva's choice of terminology introduces the notion of a conflict or agon that is always already within the fabric of the text itself, and this conflict engenders a similar one between text and reader. Cixous's L'Ange au secret is saturated with a vast array of references to authors and literary texts, from Homer, Virgil, Dante and Shakespeare to Poe, Dostoyevsky, Kafka, Bachmann, Bernhard and Lispector. For Cixous's readers, this is more than just literary name-dropping; such blatant intertextuality must always have repercussions on the politics of reading. So wide a spectrum of references can be experienced as a sort of textual terrorism, inducing anxiety and alienation in readers whose own reading histories do not necessarily include the same set of authors or texts, and yet who, by means of these very references are made to feel that their knowledge of them is assumed. 
Cixous's intertextuality does, however, also work in a more generous way, particularly in cases where references are extended and elaborated in order to illustrate a particular point. In L'Ange au secret, references to other literary texts combine with strategies such as direct reader address to involve the reader in a discussion of crime and guilt, with the association, over several sections of the text, of Dostoyevsky's The Devils with Poe's 'The Murders in the rue Morgue', both of which portray death occurring behind closed doors. ${ }^{14}$ Cixous's narrator explicitly emulates the narrative style employed in Poe's short-story to draw her reader along in a re-evaluation of the crime of the rape of a young girl to which Dostoyevsky's character, Stavrogin, confesses. Pointing to a narrative gap in Stavrogin's confession, she suggests that the girl's own desire for him makes her unrapeable; in actual fact his real crime is far worse, far worse even than the bestial murders of Poe's tale - that of subsequently and knowingly driving the girl to suicide. This point forms the basis of a self-reflective sequence in which the narrator, once again by direct address ('Et vous?' (133) (And what about you?)), encourages the readers to examine their own consciences. Although a greater sense of inclusion is to be experienced by readers who are familiar with both The Devils and 'The Murders in the rue Morgue', in this particular instance, extended discussion, clear references and sufficient commentary are given not to alienate the uninitiated reader. Indeed, such forms of intertextuality are generous, leading the readers not only out of the text they are reading by offering opportunities for further reading and (re)interpretation, but also within themselves, in this instance to prompt ongoing reflection about ethical issues.

Cixous's poetical writing style is a strong element in the politics of reading. The sensuality, rhythm and language games of her writing strengthen other effects which involve the reader in the text. In Déluge, the reader is drawn into the text by means of the 
narrator's meditation on the inadequacy of language to describe the nuances and subtleties of the feelings she is trying to convey:

Il fait si sombre ici où je cherche une langue qui ne fait pas de bruit pour chuchoter ce qui n'est ni vivant ni mort. Tous les mots sont trop forts, trop rapides, trop assurés, je cherche les noms des ombres entre les mots, comment s'appellent les choses qui restent, Comment s'appelle l'amour qui reste après l'amour Je t'aime n'est pas vrai, je ne t'aime pas est faux. (111) (It is so dark here where I seek a language that makes no sound to whisper what is neither living nor dead. All the words are too loud, too fast, too sure of themselves, I am searching for the names of the shadows between the words, what to call the things that are left,

What is the love called which remains after love has gone

I love you is not right, I do not love you is wrong.)

In addition to being programmed to reflect on the limitations of words, here the reader is sensitized to the poetical possibilities of the language used to describe its own inadequacies. Paradoxically, in this lamentation of a lack of appropriate words, the liberating potential of language is brought to the fore as the inexpressible ('the shadows between the words') is in this very way actually, poetically, expressed.

Cixous's poetical writing is seductive and this can be as controlling as it is generous; the confiding nature of the last example positions its readers to share the narrator's viewpoint as well as offering them the pleasures and possibilities of the 
aesthetics of the writing. Elsewhere in Déluge, the use of rhythm seems designed to draw the readers in and hold them within the text:

Et toujours se demandant qui tue qui, qui m'a tuée, qui tué-je, qui tues-tu toi qui me tues qui frappes-tu en moi, et moi qui en toi désiré-je soit abattre en pleine poitrine soit égorger qui désiré-je mordre au sang qui cracher, qui jeter par la fenêtre, et toi qui en moi enterres-tu vivante, qui veux-tu déporter, recouvrir de tonnes de temps, et moi qui foudroyer du regard qui agenouiller qui (203-4)

(And always wondering who kills who, who killed me, who did I kill, who do you kill you who kill me who do you strike in me, and me who in you do I desire either to strike right in the heart or to slit their throat who do I desire to bite and draw blood who to spit out, who to throw from the window, and you who in me do you bury alive, who do you want to exile, to cover up with tons of time, and me who to look daggers at who to bow down who)

Although in translation the impact of the alliteration between tu (you) and tue (kill) of the French original is lost, the intensity of the passage is still felt in its rhythm. The paragraph ends without punctuation in mid-sentence. The following paragraph of the text continues the interrupted sentence without an initial capital letter, and this format is sustained for two pages. Each unfinished paragraph draws the reader onto the next. The breaks are like pauses for breath, a coming up for air, before the text plunges once again into the maelstrom of self-reflection it evokes, including the readers by direct address and holding them within it, to encourage, or even lead them into a similar meditative mode. In reality, 
the effects of reading are not of course as predictable as this, and alternatively, this very intensity might have the opposite effect - that of alienating the reader.

Déluge is an account of a woman's abandon by her lover, but it also relates to abandonment in a more universal way, involving the reader by means of slippages from a first person singular narrative to an unspecified, general 'we':

Nous ne savons pas ce que trahir-et-abandonner veut dire. La trahison dans la nature humaine est infinie. Nous ne pouvons même pas imaginer le millionième de nos trahisons. De nos sentiments de trahisons. La trahison nous trahit. Nous trahisonne. Nous-même nous nous trahissons dix fois, cent fois par jour, nous nous ôtons nous-même le pain de la bouche, nous laissons tomber dans l'escalier l'enfant que nous avons sauvé du feu. Je ne nous comprendrai jamais. L'amour nous échappe, la nature humaine nous échappe. Heureusement. Loin de nous

la trahison trahit. (159)

(We don't know what betray-and-abandon mean. Betrayal is infinite in human nature. We can't begin to imagine one millionth of our betrayals. Of our feelings of betrayal. Betrayal betrays us. We betray. ${ }^{15}$

We betray our own selves ten times, a hundred times a day, we take the bread out of our own mouths, we let the child we rescued from the fire fall down the stairs. I will never understand us. Love escapes us, human nature escapes us. Thank goodness. Far from us 
In this extract, 'we' overtly refers to humanity as a whole but the effect of its repetition and of the incantational quality of the passage is to reinforce the inclusion of the individual reader: everyone is capable of hurting and being hurt; we, ourselves, hurt and are hurt; I personally, hurt and am hurt. The indentation of the last line breaks the rhythm and focuses attention on the slippage of the final words. Although we as individuals may be complicit with humanity's failings, this does not mean those failings are necessarily part of our own character. It is possible for us, personally, to live differently and, by the way we act, to resist those failings. In this way, readers are led by the text into themselves to reflect beyond the relationship portrayed in the text, on relationships in general, and especially, on their own. This is perhaps one of the most seductive and generous aspects of reading Cixous's fiction: the poetical evocation of internal, emotional reality makes the slippage from her non-realist texts to the lived reality of the reader an easy, even an inevitable passage. In this sense, Cixous's fictions are about ourselves, but far from making the unacceptable assumption that everyone thinks and feels like her narrative figures, this is to say instead that the passage between text and reality is an open-ended and individual one, allowing each reader his or her own pathway. Cixous's readers are always constructed as active; plenty of space is allowed for the reader's imagination, and multiple interpretations are made possible by means of the uncertainty inscribed in the fabric of the text: ambiguous language and genre, uncertain chronology and narrative voice, slippages between figures, between time, between narrative levels, between dream and reality, between inside and outside, between text and life.

The aforegoing analysis of the politics of reading Cixous's fiction suggests that the same textual factors have different (even opposite) effects. In practice, the features I have highlighted - the interdependence of Cixous's theory and fiction, her intertextuality 
and self-referentiality, the author-figure, reader address, linguistic and syntactical play the very factors which draw some readers in are just as likely to alienate others, which might account for some of the polarity of responses to her work. So far, I have suggested that the most generous effects of Cixous's fiction take the form of encouraging openended interpretation, and of leading the reader out of the text. The emphasis has, however, been on textual strategies and markers rather than on reader interpretation per se. As a counter-balance, and in order to evaluate the transformative potential of Cixous's fiction, the final part of this article shows how Beethoven à jamais ou l'existence de Dieu opens up to its readers real possibilities of liberation from imprisoning stereotypes of representation and from the aggression of binary thinking. In her essay, 'Le Sexe ou la tête?' ('Castration or Decapitation?'), Cixous identifies the need to work on three different aspects of 'the couple' in order to make progress towards socio-cultural change: first, the couple in binary thinking (the relation of one polarized term to another); second, the male/female couple (the gendered political relation of domination/subordination in phallogocentric culture); and third, the individual couple (the personal and loving relationship of one person with an/other). ${ }^{16}$ Beethoven à jamais ou l'existence de Dieu addresses all three.

In this text, which explores the creative potential of love, constant slippage between the figures of an un-named, contemporary male/female couple and a couple from history, Beethoven and his lover (the Immortal Beloved) renders the borders between the personal and the universal indistinct. Cixous's Beethoven both is and is not the composer Beethoven, functioning rather as a symbol of an artist dedicated to his work as well as the figure of an individual man. Above all, Beethoven provides Cixous, who has often spoken about her inability to create male characters, with a ready-made desiring 
male figure for this text about love. ${ }^{17}$ Beethoven might, however, appear to be a rather surprising choice since, although he was evidently a fascinating man, he is renowned for being unable to commit himself to a lasting emotional relationship. ${ }^{18}$ Within the text, Cixous's narrator chooses Beethoven as an exemplary character for the story she tells, on the one hand, because his writing - his music, his self-reflective diary and his letters, among which a now famous love letter to the unknown 'Immortal Beloved' - suggests and provides a way of writing about love, and on the other, because he is a 'feminine' man. In La Jeune Née, Cixous suggests that artists (men and women) have to open themselves up to sexual differences within themselves in order to create. ${ }^{19}$ In this way, as 'un homme si largement environné de musique' (76) (a man so considerably surrounded by music), a musician and artistic creator, Cixous's Beethoven figure is a 'feminine' man - different, unusual, inexplicable:

Mais dans cette histoire, l'homme pourrait tout aussi bien être une femme, pensons-nous, et simultanément nous pensons pourtant cet être-là est un homme en tout. C'est, dans la région du coeur, une hypersensibilité, une source d'alerte, au sein du feu, le point de lait.

(But in this story, the man could just as easily be a woman, we think, and simultaneously we think, but that person is a man in every way. It is, something emotional, a kind of hypersensitivity, an intuitiveness, in the bosom of passion, the place where the milk flows) 
He has qualities which are so often, and stereotypically, associated with women (sensitivity, intuition, passion, maternity), and yet he is also very much what is considered to be a 'real man'.

If the real Beethoven's actual words of love exist, in his now-published love letter, few of them appear in Cixous's text. Instead, she uses his 'style haletant' (70) (breathless style): the way his love letter, and indeed most of his correspondence, is punctuated by dashes. ${ }^{20}$ In Beethoven à jamais ou l'existence de Dieu, the section entitled 'Lettre à l'immortelle bien-aimée' (Letter to the Immortal Beloved) is written in this way, with dashes between phrases and sentences, but the words are the narrator's (and Cixous's) interpretation (fictionalization) of the passion and emotion with which the composer wrote his love-letter. Rather than his actual words, Cixous's fictional version is an interpretation of Beethoven's 'voice', in the sense of the Kristevan semiotic, or indeed of the Cixousian 'feminine' - the emotion of the voice being detectable in the interstices of the sentences he wrote. The love affair between Beethoven and his Immortal Beloved, epitomized in and by his love-letter, is echoed by, interweaves with, and slips between that of the contemporary couple - 'her' and 'him'. The lack of consistent differentiation between the two couples means it is not always possible to tell whether the pronoun 'he', the initial 'B', or even the name Beethoven, relate to the figure of Beethoven himself or to the contemporary man. The unnamed couple therefore also figure more conceptually as a couple in love (any couple in love, arguably even, at times, all couples in love). ${ }^{21}$

Their love story is, however, no conventional tragic or fleeting romance.

Beethoven à jamais ou l'existence de Dieu is concerned with the possibilities of a lasting passion, at once evoking and differentiating itself from such great tragic romances as Tristan and Isolde, as well as from the trite clichés of much contemporary romance. The 
'God' (ieu) of the title makes reference to the transcendental and immortal dimension of both love and artistic creation, which enables us to experience extreme heights of emotion. Artistic inspiration frequently takes on mystical qualities in Cixous's work. ${ }^{22}$ In Beethoven à jamais ou l'existence de Dieu, love too is mystical; falling in love is magical. In the text, and in life, 'God' is invoked at moments of intense passion; perhaps, Cixous's narrator goes as far as to suggest, both the word and the concept 'God' exist because of the need to give expression to such moments. Despite references to external reality (a cafe, streets, traffic, telephones, planes), Beethoven à jamais ou l'existence de

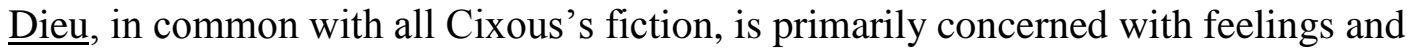
emotions, and with the importance of writing. We know of Beethoven's relationship with his Immortal Beloved only because of the love letter he wrote - an ode, and as it turns out, an attestation to the immortality of his love. In Cixous's text, diaries, notebooks, letters (real and potential), songs and narrative express the emotions of a love affair: the intensity of life, fear of loss, joy, hurt, togetherness and separation, the implications of becoming a couple.

Following Déluge, which is concerned with the pain of loving and hurting, Cixous turns in Beethoven à jamais ou l'existence de Dieu to the close analysis of some positive, creative aspects of relationships. Beethoven's 'feminine' (different) voice is present in the promises the man makes to the woman, promises which are part of the (self-)construction of the couple and of their creativity. Two of these promises warrant particular attention: 'Je te serai toujours infidèle, comme à moi-même' (71-2) (I shall always be unfaithful to you as I am to myself) and 'Je ne t'épouserai jamais' (82) (I shall never marry you). The first, 'I shall always be unfaithful to you as I am to myself' is of course a confession but a promise is implicitly contained within it. Music is what comes 
first in the man's life (in Beethoven's life) and it always will, but that does not mean he will betray his beloved. On the contrary, by means of this promise, he puts her on an equal footing with himself. To forget himself (his own needs) for his music is not to betray himself; rather, it is to be true to himself. And so, 'A l'infini, fidèle et infidèle se rejoignaient aussi' (72) (In infinity, fidelity and infidelity were also at one). Here the binary opposition between fidelity and infidelity is dissolved, the relations between the terms changed, and productively, creatively, although perhaps only momentarily, fidelity is contained within infidelity. When Cixous's Beethoven declares his infidelity, he is trusting his beloved with a part of himself, and paradoxically he is pledging that he will be faithful to her.

The second promise, 'I shall never marry you', is followed by several pages of meditative and interrogative narrative introspection, in which the phrase is examined, explored and discussed by the narrator, on behalf of, and with, not only the woman in the text but also Cixous's readers. The phrase perplexes because it is not an answer to a question. There has been no question. It is a free-floating statement, but between the words and meaning is the man's voice, its tone, its inflections, giving meaning to the words which are spoken. It is the man's voice and his intonation, saying 'never' as if he were saying 'always', insisting that this phrase is interpreted as a promise and not a warning. Cixous's readers are not however left to find this interpretation for themselves; it is made abundantly clear in the text:

Toujours - (...) toujours - je ne t'épouserai pas - et jamais je ne t'aurais épousée - et à la fin - jamais - si tu veux bien - je ne t'aurai épousée - 
tu m'entends - je t'entends, oui - je veux bien - et je m'entends avec toi t'écouter - goutte à goutte - j'écoute chaque goutte tomber suivie - tu me suis - oui je te suis goutte à goutte - et ensuite j'écoute le à qui respire d'une goutte à l'autre - les sons entre les mots je les écoute et là où il n'y a pas de son pour faire la liaison - j'écoute le silence qui célèbre le temps - (87)

(Always - (...) always - I shall not marry you - and never would I have married you and in the end - never - if you'd like - I would not have married you -

you hear me - yes, I hear you - I'd like to - and I hear myself with you listening to you - drop by drop - I listen to each drop falling followed - you follow me - yes I follow you - drop by drop - and then I listen to the sound between one drop and another - the sounds between the words I listen to them and where there is no sound - I listen to the silence celebrating time - )

Here, as in Cixous's next fiction text, La Fiancée juive de la tentation, conventional marriage and its vows are rejected in favour of the greater commitment of a pledge or promise between lovers. ${ }^{23}$ Beethoven à jamais ou l'existence de Dieu ends on a performative, creative note, as the couple say 'Jetaime' (235) (Iloveyou). The words are run together; the phrase is a cliché. It is clear, however, that this couple have dispensed with the empty, automatic promises that so often go with conventional declarations of love. Their promises, and the phrase 'Iloveyou', are meaningful in the context of their own relationship. Clichés are shattered and re-formulated differently.

In both cases, a particular interpretation of the promise is given in the text, and thus we might wonder whether any creative space remains for the reader. Is this just another example of the controlling nature of Cixous's writing? Of course, not all readers 
will be seduced by Cixous's play between language and meaning here. However, the very non-conventionality of the promises and, in particular, the long process of reflection connected with the latter one would seem actually to provide readers with food for thinking differently. Rather than reducing the interpretive opportunities, the open-ended nature of Cixous's writing encourages her readers to reflect creatively about language, about meaning, about promises, about relationships, about their own relationships. Beethoven à jamais ou l'existence de Dieu is worked through with elements of creativity - music, writing, interpretation, fiction, poetical language and love all figure in the text itself - and this, together with the usual prevalence of Cixousian textual slippages, encourages readers to read creatively, in the interstices between historical periods, between narratives, between figures, between language and meaning, between imagination and reality, and between the text and real life. The problems that Cixous's couple encounter in Beethoven à jamais ou l'existence de Dieu are not the stuff of farfetched fantasy, nor are their solutions utopian; rather, they readily find echoes in the ordinary but often painful reality of many people's lives. Moreover, since the real subject of Beethoven à jamais ou l'existence de Dieu is love itself, I would go so far as to suggest that the questions it raises about how we love one another and the individual creativity that love can produce may even be relevant beyond the boundaries of the heterosexual configuration of the couples within the text.

The between-ness that is created in Beethoven à jamais ou l'existence de Dieu encourages a dialogue between text and reader on a different dimension - in extasis beyond the limitations of ordinary language and the enclosure of binary thinking. The textual space is a creative space of individual negotiation for the reader, who is led beyond the text, beyond even the constraints of his or her own life, to recognize that 
realities of difference are actually to be found within the self, and that the potential of those realities can be realized in his or her own lived relationships. Cixous's fiction will no doubt continue to be beset with conflicting reactions and a minority status, but this does not necessarily negate its transformative impact. Individual interventions of difference into the social order can eventually make a difference on a larger scale.

To analyse Cixous's fiction through a politics of reading is admittedly rather a brutal way of looking at such nuanced poetical writing but, as this article shows, the model of a dialogue for reading does include the provision of a response to aesthetics - to voice, tone, inflection, stress. The reader may to some extent be controlled, seduced (although not always successfully), but in Cixous's case this control, seduction, is ultimately generous, since it can engage the reader in an interaction with the text well beyond the moment of reading. To read Cixous positively is perhaps to be a complicit partner to her textual seductions but it is never to be a passive one. Far from only offering utopian visions, her recent fiction opens up spaces in both internal and external reality, within the self and in relations with others, which, while offering food for thought, do not deny the force of either socio-cultural expectations or the individual power relations that operate on personal relationships in reality. Cixous's fictions may be difficult but the effort involved in reading them is productive. They lead the reader to think anew but they do not necessarily prescribe set alternatives; rather, they make the reader do the work, fostering a productive and creative interaction between text and life, initiating a reading dialogue which is not only agonistically (agonizingly) political but also out/standingly (ecstatically) meaningful. 
Institute of Romance Studies (University of London) and University of Surrey Roehampton 